\title{
NOTES ON THE ASH-YIELD OF CRUDE DRUGS AND COMPOUNDS.
}

\author{
By W. Chattaway and C. G. Moor. \\ (Read at the Meeting, April 1, 1903.)
}

The Pharmacopoia (1898) includes ash-limits for a number of crude drugs, and it is probable that in the next edition limits may be set for several others which have been frequently shown to contain very considerable amounts of mineral matter, either collected inadvertently or deliberately added.

In the case of a number of drugs-such, for example, as are used for obtaining an oil, and are not used or sold in powder-the ash is of but little interest, while in certain others its amount is a useful guide to the value of the drug in question.

In grinding drugs it must be recollected that there will be a loss of moisture and in some cases of volatile oil, which will cause the ash of the powder to be greater than that of the crude drug.

In addition to this, the process of sifting may cause accumulations of mineral matter in certain grades, and, again, the vibration of machinery may cause a settlement of mineral matter to the bottom of a package.

These considerations will show that great caution must be used in regarding a ground drug to be adulterated on account of a slight apparent excess of mineral matter, but we believe that the figures given here will indicate fairly what should be expected from samples of good quality.

A large number of figures on the ash-yields of drugs were submitted to the Pharmaceutical Conference in 1900, in a paper by C. G. Moor and Martin Priest; and since then certain ash-limits have been laid down in an official publication of the Local Government Board for Ireland.

J. C. Umney gives (P. J., November 25, 1902) a large number of suggested standards of ash for drugs, and in his Laboratory Report for $1902 \mathrm{Mr}$. John Barclay publishes a large number of ash determinations. An investigation of the normal ash of drugs is also being carried out in the research laboratories of the Pharmaceutical Society.

In "The Year-Book of Pharmacy," p. 176, 1902, appears an abstract of some records of ashes by L. Glaser (Pharm. Zeit., xlvi., 691, 887).

We have thought it would be of interest to members of this Society to recapitulate the results obtained, and place them on record in a convenient form, as, although much of the information is to be found in "The Year-Book of Pharmacy" and the Pharmaceutical Journal, no complete set of figures has as yet appeared in the ANALYsT on the subject.

We have therefore drawn up a tabular statement showing the results of various observers, which should be referred to in conjunction with the following remarks :

Acacia Gum.-The Pharmacopœia sets a limit of 4 per cent. of ash for this substance, and there is no difficulty in obtaining a plentiful supply satisfying this and the other official requirements. 
Aconiti Radix.-No limit for ash is specified in the Pharmacopœia. Cleaned roots give from 4.5 to 6 per cent. A clean sample of English root recently examined by us gave 4.9 per cent. of ash. Foreign root may possibly yield a higher figure, but it is excluded by the Pharmacopœia.

Aloes.-Both the official varieties yield an ash from 1 to 4 per cent. Umney suggests 3 per cent. as a suitable limit.

Ammoniacum.-The better qualities of this gum-resin yield less than 3 per cent. of ash. Umney suggests 7.5 and Dietrich 10 per cent. as limits. A sample of No. 3 quality gave as much as 15 per cent. of ash. A fair sample examined by us gave $1 \cdot 7$ per cent. of ash.

Anethi Fructus.-The ash of the clean fruit is about 6 to 7 per cent. Umney suggests a limit of 8 per cent.

Anisi Fructus.--Some varieties of this appear to give a slightly higher yield than Umney's suggested limit of 8 per cent. Barclay records a powdered root yielding 10.8 per cent.

Anthemidis Flores.-Five to 6 per cent. is the general experience.

Araroba.-This drug has frequently been shown to be very variable. in its ashyield. As the Pharmacopoeia requires it to give a certain yield of chrysarobin, it might be thought that the ash-figure was of small consequence, but, owing to its being used for other purposes than for the manufacture of chrysarobin, it is important that a limit of ash should be fixed; 7.5 per cent. is a reasonable limit. This drug appears to be far more free from mineral matter than formerly, it being not unusual to find 50 to 80 per cent. some years ago.

Arnica.-If this drug is not carefully cleaned by washing or beating it will be found to be contaminated with large quantities of adherent earth-as much as 25 per cent. of the weight of the drug. Another sample examined by us showed 9.2 per cent. of ash.

When cleaned by beating or washing the ash does not exceed 10 per cent., the limit suggested by C. G. Moor ("Standards"). Umney confirms this. Two samples cleaned and examined by us gave $9 \cdot 2$ and $9 \cdot 4$ per cent. of ash. It is essential that this root should be cleaned before grinding.

Asafotida.-The Pharmacopoia specifies the use of tears, which are much freer from accidental mineral contamination than the mass, though the latter is richer in oil. It is at present very difficult to obtain asafoetida yielding not more than 10 per cent. of ash, and a large number of observers have published figures showing 20, 30, or even over 40 per cent. of ash.

Umney confirms the suggestion of Moor and Priest that the limit should be raised to 20 per cent. for the present. K. Dietrich, on the other hand, says " the limit of ash (10 per cent.) is right, and should be adhered to " (C. and D., 1898, p. 131) ; and E. M. Holmes maintains that 10 per cent. should be the limit. Most Continental Pharmacopcias give the limit at 10 per cent.

Aurantii Cortex Siccatus.-The average of four figures (Moor and Priest) shows 6.2 per cent. of ash, which is confirmed by Umney's suggested limit of 7 per cent.

Balsam of Peru.-We suggest 1 per cent. of ash as a limit.

Balsam of Tolu.-One per cent. may also be suggested in this case. 
Belladonna Radix.-We suggest 9 per cent. of ash as a limit.

Benzoin.-The Pharmacopoia recognises both Siam and Sumatra benzoin, but suggests no ash-limit for either. On account of the high price of Siam benzoin, the Sumatra variety is almost exclusively used in pharmacy.

The German Pharmacopœia gives a limit of 2 per cent. of ash.

In the case of this drug the ash is not of great consequence, as the benzoic and cinnamic acids can be estimated, but a limit of insoluble matter (wood and bark) should be fixed. figure.

Buchu Folia.-Experience shows that 5.0 per cent. is approximately the average

Calumba Root.-Umney suggests 6 per cent. We are inclined to raise this to 8 per cent. F. H. Alcock ( $P . J ., 502,1901)$ records a case whereby he was able to detect an adulterant in calumba root by its high ash. Two samples of powdered calumba root recorded by Moor and Priest yielded 11.8 and 10.3 per cent., and may therefore not have been the official root.

Cambogia.-The Pharmacopœia gives 3 per cent. as a limit. No sample that we have examined has yielded more than 1 per cent., and possibly the official limit might be lowered to 2 per cent.

Cannabis Indica.-A sample examined by Priest gave 13.8 per cent., and two by ourselves 12 per cent., and by Barclay 15.5 per cent. Umney suggests 15 per cent. as a limit.

Cantharis. - Seven per cent. was suggested by Moor and Priest, and is official in the German Pharmacopcia. A recent sample examined by us gave 6.4 per cent.

Capsicum.-W. H. Lenton (P. J., 558, 1902) has examined several samples of capsicum, none of which yielded an ash over 6 per cent. The Pharmacopceia gives 6 per cent. of ash as a limit. This is rather low, and might be raised to 8 per cent., as samples have been found (C. G. Moor) to give over 7 per cent. of ash. A. Beythieu (abstract, $P . J ., 549,1902$ ) has, however, found samples to vary from $5 \cdot 3$ to $7 \cdot 7$ per cent. A sample examined some years ago by C. G. Moor gave 9 per cent. of ash, which was nearly half potash. Cowley and Catford have found 3 to 8 per cent. (P. J. [4], xii., 426).

Cardamoms. - The Pharmacopœia limit of ash is 4 per cent., and is designed to exclude the presence of pericarps, which yield a higher ash. As pointed out by Moor and Priest, the ash of genuine cardamoms may be over 5 per cent., and hence the limit should be raised from 4 to 6 per cent. This view is confirmed by Umney (P. J., November 15, 1902) and by Greenish (C. and D., 1901, p. 274), who also gives a description of the microscopical appearance of powdered cardamoms. Barclay (Laboratory Report) records a figure of 7.5 per cent. of ash on the fruits.

Carui Fructus.-The Pharmacopœia gives 8 per cent. for the ash-limit. It may be as low as 5.5 per cent. in our experience.

The ash-figure is of no service as a means of detecting exhausted seeds, but these can be detected by the low extractive yielded to ether.

Caryophyllum.-The Pharmacopœia limit is 7 per cent., and this is satisfactory, as a large number of samples show from 5 to 6 per cent. of ash.

Cascara Sagrada.-The ash varies from 4 to 7 per cent. 
Cascarilla.-Umney suggests 10 per cent. Eight results which we have collected all fall within this standard.

Cassia Pulp.-Barclay records 2.6 per cent., and the figure by Moor and Priest was $5 \cdot 1$.

Catechu.-The Pharmacopœia gives 5 per cent. as limit. This appears to be satisfactory.

Chiretta.-The ash is about 4 to 6 per cent.

Cimicifuga.-Umney suggests 10 per cent., which seems a little higher than necessary. A figure recently obtained by us was 5־2, and four samples examined by Moor and Priest showed from 5.6 to 7.9 per cent. Barclay records 6.2 per cent. We consider that 8 per cent. would be a suitable standard.

Cinchona Bark.-The Pharmacopœia gives no limit. Umney suggests 4 per cent., which accords with other observations.

Cinnamomi Cortex.-In Moor and Priest's paper 6 per cent. is suggested as a limit. Samples of low quality containing sweepings may exceed this, and should be condemned.

Coce Folia.-Umney suggests 8 per cent. It may be as low as 5 per cent., which was the figure obtained by us on a sample of good leaves.

Coccus. -Cochineal of the "silver grain" variety is often grossly adulterated with French chalk (see also Kebler, $P . J ., 554$, i., 1902), and the dark cochineal has been found adulterated with oxide of iron. The British Pharmacopœia limit of 6 per cent. is satisfactory, and, whatever purpose cochineal is used for, it ought to be free from intentional weighting. Merson (P. J., March 24, 1900) records a large number of ash determinations in cochineal, 3 showing over 40 per cent., 2 over 30 per cent., 5 over 20 per cent., and 3 over 10 per cent.

Colchici Cormus.-Umney suggests 3 per cent., which agrees with Moor and Priest and Barclay's figures.

Colchici Semina.-Five per cent. is a satisfactory limit.

Colocynthidis Pulpa.-The British Pharmacopoeia requires the pulp, when dried at $100^{\circ} \mathrm{C}$. (it is very hygroscopic), to yield not less than 9 per cent. of ash. There are, however, samples which yield less than this, even when quite free from seeds. This was shown by Moor and Priest's figures (P. J., July, 1900); Greenish (P. J. [4], xii., 398) also gives a figure on a genuine sample less than th required 9 per cent. J. C. Umney suggests raising the standard to 10 per cent. We are rather in favour of lowering it to 8 per cent., if all genuine colocynths ought to be included. The microscopical description published by Greenish should certainly be added.

Conii Folia.-Umney and Barclay both give 15 per cent. of ash. Two samples examined by us gave $19 \cdot 0$ and $18 \cdot 6$ per cent. of ash. cent.

Conii Fructus. - Umney suggests 7 per cent. One examined by us gave $5 \cdot 3$ per

Coriandri Fructus. - Most observers agree that 6.0 per cent. would be fair.

Crocus. - The British Pharmacopœia limit is 7 per cent., which is apparently founded on Barclay's work ( $P . J_{\text {., }}$ xxiv., 692 ). All genuine specimens appear to fall within this limit.

From time to time very gross adulterations of saffron with mineral matters, such 
as barium sulphate, are found. "Alicante saffron" is more often adulterated than not. It would be well if the British Pharmacopoia tests were supplemented by a colour test with sulphuric acid.

Cubeba Fructus. - Umney suggests 7 per cent. We would suggest 9 per cent. Barclay's figures are 6.4 and $7 \cdot 3$ per cent.

Cusparia Cortex.-We would place it at 8 per cent. Barclay gives 8.0 per cent. Cusso.--Umney suggests 7 per cent. We have found 5 per cent.

Digitalis Folia.-Umney suggests 10 per cent.; Barclay records finding $11 \cdot 2$; two samples examined by Priest gave $8 \cdot 1$ and 10.6 per cent.; Hockauf found 7 to 10 per cent.

Elaterium.-A sample examined by Priest gave 7.9 per cent., and one by ourselves $3 \cdot 7$ per cent., so that Umney's figure of 14 appears somewhat high.

Ergot.-The ash of ergot is about 4 per cent.

Eucalypti Gummi.-We would suggest 1.0 per cent.

Euonymi Cortex.-Ten per cent. would appear to be correct.

Filix Mas.-This, when freed from adherent earth, gives about 4 per cent. of ash. As it is only used to make the liquid extract, its ash-figure is of no importance.

Frniculi Fructus.-The ash varies from 7 to 13 per cent. (Moor, "Standards"). Galbanum.-Umney suggests 8 per cent., with which we agree.

Galla.-Umney suggests 3 per cent.; Moor and Priest found 2.3 and 1.3 per cent. ; we have found one yielding 4 per cent. and another $4 \cdot 2$ per cent.

Gelsemii Radix.-Umney suggests 3 per cent., which confirms our figures.

Gentiance Radix.-We suggest 4 per cent.

Glycyrrhiza Radix.-Umney gives 4 per cent., with which we agree.

Granati Cortex.-Moor ("Standards ") published four figures of 14.3, 13.1, 13.7, and 15.5 . A figure recently obtained by us is $13 \cdot 2$, so that Umney's suggested standard of 15 per cent. is satisfactory. The low figure 4.3 recorded by Moor and Priest probably referred to Cortex granati fructus.

Guaiaci Resina.-Umney suggests 3 per cent., which would exclude some of the lower qualities. A standard to exclude excessive woody matter is needed.

Hcematoxyli Lignum. - The ash is about 3 per cent.

Hamamelidis Cortex.-The ash is 4 to 5 per cent.

Hamamelidis Folia.-The ash should not exceed 9 per cent.

Hemidesmi Radix. - The ash should not exceed 9 per cent.

Hydrastis Rhizoma. - When cleaned the ash is about 8 per cent. It should not exceed 12 per cent. A sample recently examined by us gave $7 \cdot 4$ per cent.

Hyoscyami Folia.-The ash varies from 8.5 to 12 per cent. Barclay records two very high figures, 21.9 and 14.0 per cent. Umney suggests 12 per cent. as a standard.

Ipecacuanha Radix.-When quite clean the ash is about 2.5 to 3 per cent. A limit of 5 per cent. was suggested by Moor and Priest ( $v$. B. P., 1900). This is confirmed by Umney (November 1902), and by W. J. Lenton (P. J., i., 558, 1902).

Jaborandi Folia.-We suggest 9 per cent. as a limit. Barclay gives three figures of 4 to 5 per cent.

Jalap.-The ash is about 6 per cent., but is of no consequence, as a resin standard is required by the British Pharmacopoeia. 
Kino.-Umney suggests 2 per cent., which is satisfactory.

Kramerice Radix.-The ash is usually from 1.5 to 2 per cent.

Limonis Cortex.-Should not exceed 6 per cent.

Linum.-The British Pharmacopœia limit is 5 per cent., and is satisfactory.

Lobelia.-Umney suggests 12 per cent. of ash as a standard. Barclay's figures are much lower.

Lupulinum.-The British Pharmacopœia limit is 12 per cent. Umney would raise it to 14 per cent. Seven out of eight samples examined by Squire ("Companion ") gave over 20 per cent.

Lupulus.-The ash of hops is about 8 per cent., and should not exceed 10 per cent. Three samples recently examined by us gave $8 \cdot 3,7 \cdot 8$, and $7 \cdot 2$ per cent. of ash.

Mezerei Cortex.-Umney gives 4 per cent. as a limit, with which we agree.

Moschus.-The British Pharmacopoia limit is 8 per cent., and should be maintrined.

Myristica.-The ash of nutmegs is about 3 per cent., unless they have been whitewashed, when it may be 5 per cent.

Myrrha.-C. G. Moor ("Standards") suggested 6 per cent. as a limit. This would exclude a considerable number of commercial samples. C. F. Merson (P. J., 44,1900 ) suggests 5 per cent. as a limit of ash; Dietrich (C. and D., 131, ii., 1898) suggests 10 per cent.

Nux Vomica.-The ash is about 1 to 2 per cent.

Papaveris Capsulce.-The ash is 9 to 11 per cent.

Pareira Brava.-The ash is from 3 to 5 per cent. An ash of stem by Moor and Priest was 8 per cent., and two samples of Bahia pareira yielded less than 2 per cent. A sample of genuine pareira examined by us showed 4.3 per cent.

Physostigmatis Semina.-The ash is from 3 to 4 per cent.

Pimento.-Moor ("Standards") suggested 5 per cent., which is confirmed by Umney.

Piper Album.-The ash varies from 1 to 3 per cent.

Piper Nigrum.-The ash varies from 4 to 7 per cent.

Pix Burgundica.-Umney suggests 1 per cent. as a limit.

Podophylli Rhizoma.-The ash is about 3 per cent.

Pruni Virginiance.-The ash is from 4 to 6 per cent.

Pterocarpi Lignum. - The ash is about 2 per cent. Umney suggests 1 per cent.; Moor and Priest record $1 \cdot 7$ per cent.

Pyrethri Radix.-The ash is about 4 to 6 per cent., but commercial samples (powdered) have been found showing 18 per cent. A genuine sample recently examined by us yielded 3.6 per cent.

Quassice Lignum. - The ash is from 3 to 4 per cent.

Quillaice Cortex.-Umney suggests 12 per cent. We have found 14 per cent., and another sample recently examined yielded 11 per cent.

Rhei Radix.-Umney suggests 12 per cent. as a limit. This is correct for most specimens, but some rhubarbs yield an ash up to 28 to 30 per cent., most of which is due to calcium salts. Two samples recently examined yielded $28 \cdot 7$ and $29 \cdot 8$ per cent. 
Rhceados Petala.-The ash should not exceed 16 per cent. (Umney). Priest examined a sample yielding 20 per cent.

Rosa Gallice Petala.-The ash is about 3 per cent. A sample recently examined showed $2 \cdot 8$ per cent.

Saccharum Lactis. - The British Pharmacopœia gives a limit of 0.25 per cent. It may be lower with advantage.

Sambuci Flores. - The ash is from 9 to 10 per cent.

Sarsa Radix.-Umney gives 8 per cent. as a limit, which is satisfactory.

Sassafras Radix.-The ash is about 1 per cent. A sample recently examined showed 0.58 per cent.

Scammonice Radix.-The ash is about 10 to 12 per oent.

Scilla.-Umney suggests an ash limit of 4 per cent., which is satisfactory. The limit of water should be fixed at 20 per cent.

Scoparii Cacumina.-The ash is 3 to 4 per cent.

Senegce Radix.-The true ash is about 4 per cent. Moor and Priest record a commercial specimen of powdered root giving 20 per cent.

Senna.-The figures recorded by Moor and Priest varied from 5.6 to 10.5 per cent. H. G. Greenish (Pharm. Journ. [4], xii., 397) determined the ash in a number of commercial sennas, and recommends a limit of 14 per cent., which should be almost entirely soluble in hydrochloric acid.

Serpentarice Rhizoma.-Moor ("Standards") suggests 10 per cent. Umney confirms this. Cleaned specimens yield about 8 per cent., but two commercial powdered specimens were found by Moor and Priest giving 18 per cent., and even 30 per cent., of ash.

Sinapis.-The ash of mustard should be about 5 per cent.

Staphisagria Semina.-When clean, these yield about 14 per cent. A commercial sample containing dirt, which gave 26 per cent. of ash, was recorded by Moor and Priest.

Stramonii Folia.-The ash is about 12 per cent. in powder; it should not exceed Umney's limit of 15 per cent. A sample recently examined by us gave 11.0 per cent.

Stramonii Semina.-The ash is 3 to 4 per cent.

Strophanthi Semina.-The ash is about 3 to 5 per cent. A sample recently examined showed $4 \cdot 7$ per cent.

Sumbul Radix.-Umney's limit of 6 per cent. is satisfactory.

Uva Ursi Folia. - The ash is 3 to 4 per cent.

Valeriance Rhizoma.-Moor suggests 9 per cent., Umney 10 per cent. Com. mercial samples often contain double, or even more. Barclay records a ground sample showing 17 per cent. ; at least half of this must have been mineral matter. Two samples of root of good quality but insufficiently cleaned yielded us 11.2 and 16.0 per cent.

Zingiber.--The average ash is about 5 per cent. Coated or limewashed samples may sometimes give a little more. The amount of ash soluble in water is the chief criterion of genuineness, and this should never be less than 1.5 per cent. 
THE ANALYST.

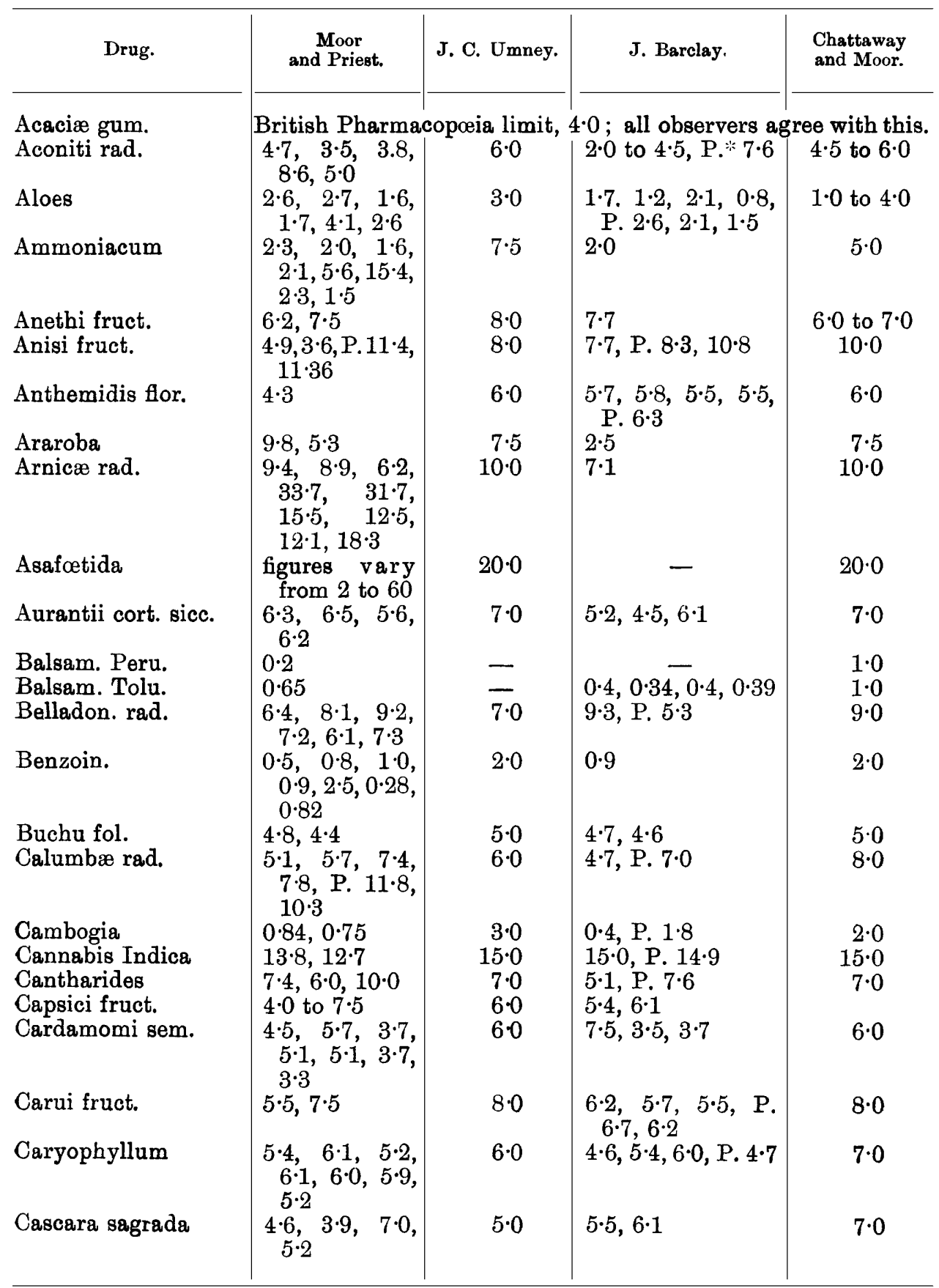

* The letter $P$ indicates that the sample was in powder. 


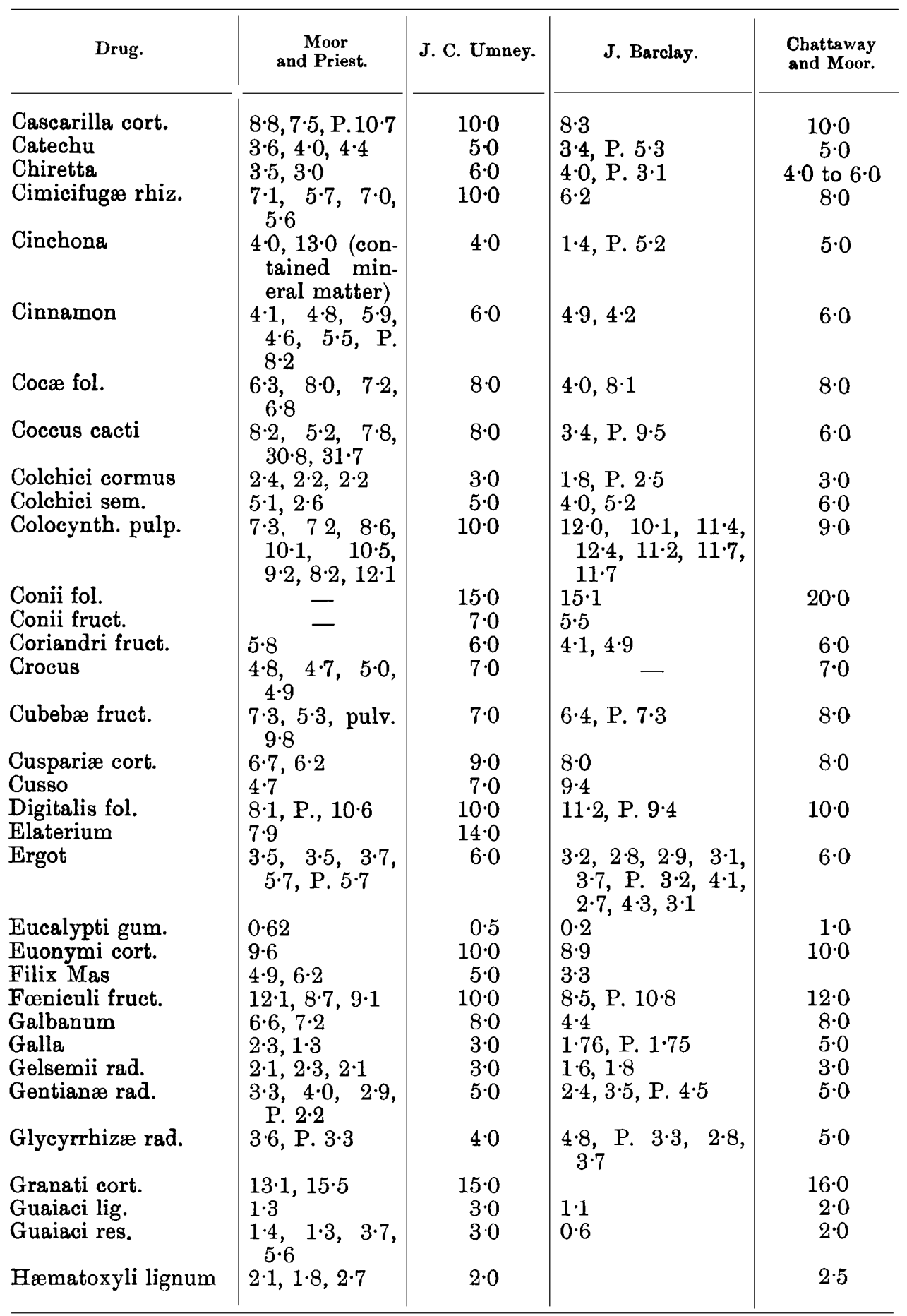


THE ANALYST.

\begin{tabular}{|c|c|c|c|c|}
\hline Drug. & $\begin{array}{l}\text { Moor } \\
\text { and Priest. }\end{array}$ & J. C. Umney. & J. Barclay. & $\begin{array}{l}\text { Chattaway } \\
\text { and Moor. }\end{array}$ \\
\hline $\begin{array}{l}\text { Hamamelidis fol. } \\
\text { Hamamelidis cort. } \\
\text { Hemidesmi rad. } \\
\text { Hydrastis rhiz. } \\
\text { Hyoscyami fol. }\end{array}$ & $\begin{array}{l}8 \cdot 5,5 \cdot 1,4 \cdot 6 \\
4 \cdot 7,5 \cdot 1,5 \cdot 0 \\
4 \cdot 4 \\
12 \cdot 0,8 \cdot 5,4 \cdot 7 \\
11 \cdot 8,8 \cdot 6\end{array}$ & $\begin{array}{r}8 \cdot 0 \\
5 \cdot 0 \\
4 \cdot 0 \\
10 \cdot 0 \\
12 \cdot 0\end{array}$ & $\begin{array}{l}5 \cdot 5,4 \cdot 3 \\
3 \cdot 4 \\
3 \cdot 7 \\
4 \cdot 3 \\
21 \cdot 9 \quad \text { Exot., } 14 \cdot 0 \\
\text { Ang., } \quad 12 \cdot 4 \quad P \text {. } \\
\text { Ang. }\end{array}$ & $\begin{array}{l}8 \cdot 0 \\
6 \cdot 0 \\
5 \cdot 0\end{array}$ \\
\hline Ipecacuanhæ rad. & $\begin{array}{c}3 \cdot 2,2 \cdot 1, \quad 2 \cdot 9, \\
2 \cdot 5,3 \cdot 1\end{array}$ & $5 \cdot 0$ & $2 \cdot 0$ to $3 \cdot 4$ & $5 \cdot 0$ \\
\hline Jaborandi fol. & $\begin{array}{cc}6 \cdot 0,8 \cdot 1, & \text { P. } \\
11 \cdot 7 & \end{array}$ & $7 \cdot 0$ & $4 \cdot 5,4 \cdot 6,4 \cdot 2,4 \cdot 0$ & $8 \cdot 0$ \\
\hline Kino & $1 \cdot 4$ & $2 \cdot 0$ & $0 \cdot 8$ & $2 \cdot 0$ \\
\hline Krameriæ rad. & $1 \cdot 6$ & $2 \cdot 0$ & $2 \cdot 5$, P. $4 \cdot 4$ & $2 \cdot 0$ \\
\hline $\begin{array}{l}\text { Limonis cort. } \\
\text { Linum }\end{array}$ & $\begin{array}{l}4 \cdot 9,5 \cdot 3 \\
3 \cdot 6,3 \cdot 3,3 \cdot 6\end{array}$ & $\begin{array}{l}5 \cdot 0 \\
5 \cdot 0\end{array}$ & $\begin{array}{l}3 \cdot 7 \quad- \\
-\end{array}$ & $\begin{array}{l}5 \cdot 0 \\
5 \cdot 0\end{array}$ \\
\hline Lobelia & $9 \cdot 0$ & $12 \cdot 0$ & $\begin{array}{c}3 \cdot 4,4 \cdot 7,3 \cdot 8, \mathrm{P} . \\
9 \cdot 5\end{array}$ & $10 \cdot 0$ \\
\hline Lupulinum & $15 \cdot 6$ & $14 \cdot 0$ & $13 \cdot 4$ & \\
\hline Lupulus & $10 \cdot 8$ & $7 \cdot 0$ & $6 \cdot 9,7 \cdot 5$ & $10 \cdot 0$ \\
\hline Mezerei cort. & $3 \cdot 1,3 \cdot 0$ & $4 \cdot 0$ & $3 \cdot 1$ & $4 \cdot 0$ \\
\hline Moschus & $5 \cdot 2$ & $8 \cdot 0$ & $x^{2}$ & $8 \cdot 0$ \\
\hline Myristica & $2 \cdot 4,2 \cdot 1$ & $4 \cdot 0$ & $1 \cdot 9,1 \cdot 7$, P. $2 \cdot 5$ & $5 \cdot 0$ \\
\hline Myrrha & $\begin{array}{c}3 \cdot 8, \quad 3 \cdot 6, \quad 9 \cdot 9 \\
4 \cdot 2,17 \cdot 0,3 \cdot 2, \\
9 \cdot 8,9 \cdot 8,3 \cdot 8\end{array}$ & $6 \cdot 0$ & $\begin{array}{l}2 \cdot 6,2 \cdot 6,6 \cdot 7, \quad \text {. } \\
9 \cdot 8,10 \cdot 7\end{array}$ & $6 \cdot 0$ \\
\hline Nux vomica & $2 \cdot 0,1 \cdot 3,1 \cdot 1$ & $2 \cdot 0$ & $1 \cdot 1,2 \cdot 4$ & $2 \cdot 0$ \\
\hline Papaveris capsulæ & $9 \cdot 1$ & $10 \cdot 0$ & $11 \cdot 3,8 \cdot 6$ & $12 \cdot 0$ \\
\hline Pareiræ rad. & $3 \cdot 4,3 \cdot 6,3 \cdot 5$ & $4 \cdot 0$ & $2 \cdot 5$ & $5 \cdot 0$ \\
\hline Physostigmatis sem. & $3 \cdot 9$ & $4 \cdot 0$ & $3 \cdot 1$ & $4 \cdot 0$ \\
\hline Pimento & $4 \cdot 2$ & $5 \cdot 0$ & & $5 \cdot 0$ \\
\hline Piper album & $1 \cdot 0$ to $3 \cdot 0$ & $\overline{70}$ & $3 \cdot 3$, P. $6 \cdot 3$ & $\begin{array}{l}3.0 \\
1.0\end{array}$ \\
\hline $\begin{array}{l}\text { Piper nigrum } \\
\text { Podophylli rhiz. }\end{array}$ & $\begin{array}{l}4 \cdot 0 \text { to } 7 \cdot 0 \\
2 \cdot 9\end{array}$ & $\begin{array}{l}7 \cdot 0 \\
5 \cdot 0\end{array}$ & $\begin{array}{l}3 \cdot 3, \text { P. } 6 \cdot 3 \\
3 \cdot 2\end{array}$ & $\begin{array}{c}4 \cdot 0 \text { to } 7 \cdot 0 \\
5 \cdot 0\end{array}$ \\
\hline Pruni Virg. cort. & $\begin{array}{c}5 \cdot 1,4 \cdot 2, \quad 4 \cdot 0 \\
4 \cdot 6\end{array}$ & $6 \cdot 0$ & $2 \cdot 9$ & $6 \cdot 0$ \\
\hline $\begin{array}{l}\text { Pterocarpi lig. } \\
\text { Pyrethri rad. }\end{array}$ & $\begin{array}{l}1 \cdot 7 \\
6 \cdot 0,5 \cdot 3,4 \cdot 9, \\
\quad \text { P. } 18 \cdot 5,17 \cdot 5\end{array}$ & $\begin{array}{l}1 \cdot 0 \\
5 \cdot 0\end{array}$ & $\begin{array}{l}1 \cdot 2 \\
3 \cdot 9\end{array}$ & $\begin{array}{l}2 \cdot 0 \\
6 \cdot 0\end{array}$ \\
\hline $\begin{array}{l}\text { Quassiæ lig. } \\
\text { Quillaiæ cort. }\end{array}$ & $\begin{array}{l}3 \cdot 4,3 \cdot 7 \\
14 \cdot 6,14 \cdot 1\end{array}$ & $\begin{array}{r}4 \cdot 0 \\
12 \cdot 0\end{array}$ & $\begin{array}{l}2 \cdot 5 \\
8 \cdot 0,8 \cdot 2\end{array}$ & $4 \cdot 0$ \\
\hline Rhei rad. & $\begin{array}{c}12 \cdot 2,11 \cdot 0, \quad \mathrm{P} . \\
7 \cdot 4\end{array}$ & $12 \cdot 0$ & $\begin{array}{l}4 \cdot 9,7 \cdot 3, \text { P. } 8 \cdot 8 \\
10 \cdot 7\end{array}$ & $30 \cdot 0$ \\
\hline Rhœados petala & $18 \cdot 0,20 \cdot 0$ & $16 \cdot 0$ & - & $20 \cdot 0$ \\
\hline Rosæ Gallic. petala & $2 \cdot 8$ & $4 \cdot 0$ & $1 \cdot 8,3 \cdot 1$ & $4 \cdot 0$ \\
\hline Sarsæ rad. & $6 \cdot 5$ & $8 \cdot 0$ & $6 \cdot 0,10 \cdot 5,5 \cdot 7,5 \cdot 1$ & \\
\hline Sassafras rad. & $0 \cdot 64$ & $2 \cdot 0$ & 0.8 & $2 \cdot 0$ \\
\hline Scammoniæ rad. & $11 \cdot 1,10 \cdot 9$ & $12 \cdot 0$ & $9 \cdot 1$ & $12 \cdot 0$ \\
\hline $\begin{array}{l}\text { Scammonium } \\
\text { Scilla }\end{array}$ & $7 \cdot 9,4 \cdot 9,6 \cdot 1$ & $\overline{4} \cdot 0$ & $3 \cdot 4$ & $6 \cdot 0$ \\
\hline & $\begin{array}{ccc}3 \cdot 8, & 2 \cdot 8, & 2 \cdot 9 \\
3 \cdot 4, & 2 \cdot 5, & \text { P. } \\
2 \cdot 5 & & \end{array}$ & $4 \cdot 0$ & $2 \cdot 1$, P. $2 \cdot 5$ & $4 \cdot 0$ \\
\hline
\end{tabular}




\begin{tabular}{|c|c|c|c|c|}
\hline Drug. & $\begin{array}{c}\text { Moor } \\
\text { and Priest. }\end{array}$ & J. C. Umney. & J. Barclay. & $\begin{array}{l}\text { Chattaway } \\
\text { and Moor. }\end{array}$ \\
\hline $\begin{array}{l}\text { Scoparii cacumina } \\
\text { Senegæ rad. }\end{array}$ & $\begin{array}{l}3 \cdot 5 \\
4 \cdot 0, \quad 3 \cdot 1, \quad 4 \cdot 6 \text {, } \\
\text { P. } 24 \cdot 0\end{array}$ & $\begin{array}{l}4 \cdot 0 \\
5 \cdot 0\end{array}$ & $\begin{array}{l}2 \cdot 3 \\
4 \cdot 2,4 \cdot 4\end{array}$ & $\begin{array}{l}4 \cdot 0 \\
5 \cdot 0\end{array}$ \\
\hline Sennæ fol. & $\begin{array}{c}5 \cdot 6,8 \cdot 6,9 \cdot 1, \\
10 \cdot 9, \quad 10 \cdot 4, \\
8 \cdot 9,7 \cdot 2\end{array}$ & $14 \cdot 0$ & $\begin{array}{c}7 \cdot 9,8 \cdot 4,8 \cdot 5,7 \cdot 3 \\
8 \cdot 1,8 \cdot 6, \text { P. } 9 \cdot 4\end{array}$ & $14 \cdot 0$ \\
\hline Serpentariæ rad. & $\begin{array}{l}8 \cdot 9,30 \cdot 7,10 \cdot 1 \\
13 \cdot 4,6 \cdot 0,7 \cdot 1 \\
\text { P. 18.0, } 18 \cdot 4\end{array}$ & $10 \cdot 0$ & $5 \cdot 7,10 \cdot 1$ & $9 \cdot 0$ \\
\hline Sinapis & 4.0 to 6.0 & $\begin{array}{r}5 \cdot 0 \\
15 \cdot 0\end{array}$ & $4 \cdot 0,4 \cdot 3,4 \cdot 3$ & $4 \cdot 0$ to $6 \cdot 0$ \\
\hline $\begin{array}{l}\text { Staphisagriæ sem. } \\
\text { Stramonii fol. }\end{array}$ & $\begin{array}{l}26 \cdot 0,14 \cdot 0 \\
18 \cdot 1, \text { P. } 20 \cdot 1\end{array}$ & $\begin{array}{l}15 \cdot 0 \\
15 \cdot 0\end{array}$ & $\begin{array}{l}13 \cdot 3,11 \cdot 7 \\
20 \cdot 2,19 \cdot 3, \quad 13 \cdot 9 \\
22 \cdot 0\end{array}$ & $\begin{array}{l}15 \cdot 0 \\
20 \cdot 0\end{array}$ \\
\hline Stramonii sem. & $3 \cdot 0$ & $3 \cdot 0$ & $2 \cdot 4$ & $3 \cdot 0$ \\
\hline Strophanthi sem. & $\begin{array}{l}3 \cdot 8,3 \cdot 4, \quad 3 \cdot 4, \\
4 \cdot 0\end{array}$ & $5 \cdot 0$ & $3 \cdot 8$ & $5 \cdot 0$ \\
\hline Sumbul rad. & $5 \cdot 7$ & $6 \cdot 0$ & $6 \cdot 1$ & $7 \cdot 0$ \\
\hline $\begin{array}{l}\text { Taraxaci rad. } \\
\text { Tragacanth }\end{array}$ & $0.94 . \overline{9}$ & $7 \cdot 0$ & $3 \cdot 2$ & $7 \cdot 0$ \\
\hline Tragacanth & $2 \cdot 9,4 \cdot 9$ & $4 \cdot 0$ & $\begin{array}{c}3 \cdot 2,2 \cdot 0,1 \cdot 7, \quad \mathrm{P} . \\
2 \cdot 1,2 \cdot 2\end{array}$ & $5 \cdot 0$ \\
\hline Uvæ ursi fol. & & $4 \cdot 0$ & $2 \cdot 4$ & $4 \cdot 0$ \\
\hline Valerianæ rhiz. & $\begin{array}{cl}8 \cdot 0,8 \cdot 6, & 13 \cdot 7 \\
15 \cdot 1, & 19 \cdot 5, \\
\text { P. } 20 \cdot 9\end{array}$ & $10 \cdot 0$ & $11 \cdot 6,10 \cdot 0,17 \cdot 4$ & $9 \cdot 0$ \\
\hline Zingiber & $3 \cdot 0$ to $5 \cdot 0$ & $5 \cdot 0$ & $2 \cdot 4$ to 6 & $3 \cdot 0$ to $6 \cdot 0$ \\
\hline
\end{tabular}

Compound Powders of the British Pharmacopeia.-The Irish Local Government Board Standards include Ash figures for certain of the British Pharmacopœia Pulveres, and we have compared these figures with some obtained by ourselves:

\begin{tabular}{|c|c|c|c|c|c|c|}
\hline & & & & & C. and $\mathrm{M}$. & $\begin{array}{c}\text { I. L. G. B. } \\
3.3\end{array}$ \\
\hline , unv & Cinnamomi Co. & $\begin{array}{l}\cdots \\
\cdots\end{array}$ & $\begin{array}{l}\cdots \\
\cdots\end{array}$ & $\cdots$ & 5.9 & $4 \cdot 3$ \\
\hline 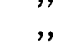 & Cretæ Aromat. & & $\ldots$ & $\cdots$ & $22 \cdot 5$ & $22 \cdot 0$ \\
\hline ," & , , , & Opio & $\ldots$ & $\ldots$ & $20 \cdot 6$ & $22 \cdot 0$ \\
\hline 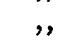 & Glycyrrhizœ Co. & $\cdots$ & $\cdots$ & $\cdots$ & $4 \cdot 1$ to $5 \cdot 3$ & 4.5 \\
\hline , & Ipecac. Co. & ... & $\ldots$ & $\ldots$ & $79 \cdot 0$ & $81 \cdot 1$ \\
\hline ", & Jalapæ Co. & $\ldots$ & $\cdots$ & $\ldots$ & $23 \cdot 2$ & $20 \cdot 0$ \\
\hline ," & Rhei Co. & $\ldots$ & $\ldots$ & $\cdots$ & 63 to 65 & $68 \cdot 0$ \\
\hline ," & Scammoniæ Co. & $\cdots$ & ... & ... & $1 \cdot 9$ & $2 \cdot 0$ \\
\hline
\end{tabular}

The Irish Local Government Board Standards are termed "suggested standards," but their Analysts are directed to condemn samples which fall below them. It seems desirable that a range should be given, as it is obvious that, however carefully prepared medicines may be, they cannot be set to correspond with a precise figure except in certain cases, which are comparatively few.

The only two substances mentioned above that call for comment are the figures for Pulv. Glycyrrhizæ Co. The total ash figure may vary from $4 \cdot 1$ to $5 \cdot 3$, but the figure for soluble ash appears to be more important, and should not fall below 2.5 . 